\title{
Postproduction of Potted Miniature Rose: Flower Respiration and Single Flower Longevity
}

\author{
José A. Monteiro, ${ }^{1}$ Terril A. Nell, and James E. Barrett \\ Department of Environmental Horticulture, University of Florida, Gainesville, FL 32611
}

\begin{abstract}
AdDitional Index words. flower senescence, Rosa sp., 'Meidanclar', 'Meilarco', 'Meijikatar', 'Meirutral', and 'Schobitet' miniature roses

Aвstract. Research was conducted to investigate the relationship between flower respiration and flower longevity as well as to assess the possibility of using miniature rose (Rosa hybrida L.) flower respiration as an indicator of potential flower longevity. Using several miniature rose cultivars as a source of variation, four experiments were conducted throughout the year to study flower respiration and flower longevity under interior conditions. For plants under greenhouse as well as interior conditions, flower respiration was assessed on one flower per plant, from end-of-production (sepals beginning to separate) up to 8 days after anthesis. Interior conditions were $21 \pm 1{ }^{\circ} \mathrm{C}$ and $50 \pm 5 \%$ relative humidity with a 12-hour photoperiod of $12 \mu \mathrm{mol} \cdot \mathrm{m}^{-2} \cdot \mathrm{s}^{-1}$ (photosynthetically active radiation). Flower respiration was higher if the plants were produced during spring/summer as compared to fall/winter. 'Meidanclar', 'Schobitet', and 'Meilarco' miniature roses had higher flower respiration rates than 'Meijikatar' and 'Meirutral'. These two cultivars with the lowest respiration rates showed much greater flower longevity if grown during spring/summer as compared to fall/winter. The three cultivars with the higher respiration rates did not show differences in flower longevity between seasons. For plants under greenhouse or interior conditions, flower respiration was negatively correlated with longevity in spring/summer but a positive correlation between these parameters was found in fall/winter. During spring/summer, flower respiration rate appears to be a good indicator of potential metabolic rate, and flowers with low respiration rates last longer.
\end{abstract}

Respiration rate is negatively correlated with organ longevity in plant postharvest physiology (Kader, 1985; Reid, 1985). In general, low respiration rate has been related to increased flower longevity in cut flowers (Kuc and Workman, 1964). In potted plants, Monteiro (1991) showed that inflorescence respiration (after $17 \mathrm{~d}$ under interior conditions) of different chrysanthemum cultivars [Dendranthema xgrandiflora Kitam. (syn. Chrysanthemumxmorifolium Ramat.)] was negatively correlated with flower longevity. The rational proposed was that the higher the metabolic rate the quicker the cell or organ perform their genetic program and the shorter the longevity. It is the principle Pearl (1928) proposed based on work with cantaloupe seedlings [Cucumis melo L. (Cantalupensis Group)]: the higher the rate of energy expenditure during life, the shorter the life span, and vice versa. The metabolic rate is thought to be determined genetically and thus, a characteristic of the species or clone (Adelman et al., 1988; Pearl, 1928).

Some postharvest treatments increase cut flower longevity as well as flower respiration. Exogenous sugar in vase solutions increases flower respiration but extends longevity in cut roses (Rosa L. sp.) (Marousky, 1969), cut carnations (Dianthus caryophyllus L.) (Nichols, 1973) and cut gladiolus (Gladiolus xhortulanus Bailey) (van der Merwe et al., 1986). Comparing spring to summer production, Çelikel and Karaçali (1991) showed that cut carnation flower longevity was best for plants produced during the summer when flower respiration rates were higher. Thus, flower respiration is not always negatively correlated with

Received for publication 19 Oct. 1999. Accepted for publication 9 Aug. 2000. Florida Agricultural Experiment Station journal series R-07209. This research was supported in part by grants from the American Floral Endowment and Junta de Investigação Científica e Tecnológica (Programa Ciência, Portugal). The cost of publishing this paper was defrayed in part by the payment of page charges. Under postal regulations, this paper therefore must be hereby marked advertisement solely to indicate this fact.

${ }^{1}$ To whom reprint requests and all correspondence should be addressed; current address: University of Algarve, UCTA, Gambelas, 8000 Faro, Portugal (e-mail: jmontei@ualg.pt.). flower longevity or it is a specificity of the cut flower system, where a substrate limitation may occur due to detachment from the source organs.

Flower respiration rate has been related to longevity of flowering potted chrysanthemum (Monteiro, 1991), but more work is needed to identify the exact meaning and usefulness of flower respiration in postproduction of potted flowering plants. Therefore, the purpose of this work was to investigate the relationship between flower respiration and flower longevity, in potted miniature rose plants (Rosa hybrida L.), as well as to assess the possibility of using flower respiration rate as an indicator of potential flower longevity.

Potted miniature rose cultivars exhibit much variability in postproduction longevity and were considered a good system to test the relationship between respiration and single flower longevity. Some cultivars have their postproduction floral longevity affected by production season and some do not (Borch et al., 1996; Kyalo et al., 1996). Cultivars whose longevity is affected by season, perform better with summer production than with winter production (Borch et al., 1996) as it is the case for 'Meirutral' and 'Meijikatar' miniature roses (Cushman et al., 1998; Kyalo et al., 1996). Whole plant net photosynthesis and dark respiration were assessed in 'Meilarco' and 'Meijikatar' miniature roses, as affected by irradiance, temperature, and $\mathrm{CO}_{2}$ levels but these carbon exchange rates were never related to flower longevity (Jiao et al., 1990). Clark et al. (1993) and Rajapakse et al. (1994), using carbon dioxide enriched atmospheres, studied the effect of higher carbohydrate levels in 'Meijikatar' rose leaf chlorosis but flower longevity was not assessed. For summer produced 'Meijikatar' and 'Meirutral' miniature roses (Cushman et al., 1998), the earlier the flower stage at end-of-production, the more flower longevity was negatively affected by shipping. For nonstored plants (Kyalo et al., 1996) the same effect is valid. Since pot roses are increasingly a popular item, an early indicator of potential flower longevity would be very useful for breeders, growers, and merchants. 


\section{Materials and Methods}

Cultural procedures. 'Meidanclar', 'Meilarco', 'Meijikatar', 'Meirutral', and 'Schobitet', miniature roses produced by Yoder Brothers (Parrish, Fla.) were planted (Apr., Sept., and Dec. 1991, and Jan. 1992) in 0.4-L plastic pots with Metro-mix 500 (Scotts, Marysville, Ohio) growing medium and placed in a fan-and-pad cooled greenhouse in Gainesville, Florida, under natural days. The greenhouse was covered with shade cloth to provide $30 \%$ light reduction. Maximum irradiance at noon, on a sunny day, measured with a quantum radiometer (LI-185A; LI-COR, Inc., Lincoln, Nebr.) at plant canopy level, was $\approx 800 \mu \mathrm{mol} \cdot \mathrm{m}^{-2} \cdot \mathrm{s}^{-1}$ in fall/winter and $1100 \mu \mathrm{mol} \cdot \mathrm{m}^{-2} \cdot \mathrm{s}^{-1}$ in spring/summer. Greenhouse environmental control was set to start heating at $18^{\circ} \mathrm{C}$ and venting at $25^{\circ} \mathrm{C}$. Average temperatures in the greenhouse were about $28^{\circ} \mathrm{C}$ in Summer 1992 and $22^{\circ} \mathrm{C}$ in Fall 1992.

At planting, all flower buds were removed by a soft pinch. Plants were pruned twice, to $4 \mathrm{~cm}$ above pot edge, when new flower buds appeared. Four planting dates were used resulting in four different end of production dates (i.e., start of each experiment). The four end of production dates were 4 Apr. 1992 (Expt. 1), 15 June 1991 (Expt. 2), 15 Nov. 1991 (Expt. 3), and 20 Feb. 1992 (Expt. 4).

Plants were fertilized at every watering with $\mathrm{N}$ at $150 \mathrm{mg} \cdot \mathrm{L}^{-1}$ (12\% nitrate, $8 \%$ ammoniacal) from a $20 \mathrm{~N}-4.8 \mathrm{P}-16 \mathrm{~K}$ water soluble fertilizer (Peters Fertilizer Products, Fogelsville, Pa.), supplemented with magnesium sulphate $\left(\mathrm{Mg}\right.$ at $\left.225 \mathrm{mg} \cdot \mathrm{L}^{-1}\right)$ and phosphoric acid for $\mathrm{pH}$ adjustment. Fertilization was terminated 1 week before petals started to reflex.

EXPERIMENTAL PROCEDUREs. Treatments were the cultivars. End of production was considered when there was at least one flower bud showing color (stage 2 as described by Cushman et al., 1994) per plant. At this time, the flower bud showing color was left and all the other buds removed by a soft pinch. One third of the plants remained in the greenhouse (for respiration assessment) and two thirds were moved to interior rooms (for respiration and longevity assessment), providing $21 \pm 1{ }^{\circ} \mathrm{C}, 50 \pm 5 \%$ relative humidity, and a $12-\mathrm{h}$ photoperiod of $12 \mu \mathrm{mol} \cdot \mathrm{m}^{-2} \cdot \mathrm{s}^{-1}$ photosynthetically active radiation $(P A R)$. Ethylene levels in the interior room for Nov. 1991 averaged $0.008 \mu \mathrm{L} \cdot \mathrm{L}^{-1}$ with a maximum of $0.016 \mu \mathrm{L} \cdot \mathrm{L}^{-1}$.

Flower longevity was established as the time between anthesis (outer petals perpendicular to the stem) and flower death (flower drop, petal wilt, petal drop or petal browning, depending on cultivar). Flower longevity was always assessed under interior conditions.

In Expts. 1, 3, and 4, flower respiration was assessed at end of production (day E), anthesis (day 0), and 2 (day 2), 4 (day 4), 6 (day 6), and 8 (day 8) d after anthesis for plants in the greenhouse and in the interior rooms. In Expt. 2, flower respiration was assessed at days E, zero, and two, for plants under simulated interior conditions and in the greenhouse.

Whole flower respiration was determined using a portable infrared gas analyzer (LI-COR 6250, LI-COR, Inc., Lincoln, Nebr.) connected to a $0.25-\mathrm{L}$ assimi- lation chamber and expressed on a dry weight (DW) basis. After the measurements, flowers were harvested and dried in a ventilated oven, at $70{ }^{\circ} \mathrm{C}$, for approximately a week, to determine flower DW. Due to seasonal variation in greenhouse environmental conditions, all respiration measurements were done in an air conditioned lab at average air temperatures of $23 \pm 0.5^{\circ} \mathrm{C}$ and with cool-white fluorescent light at $9 \mu \mathrm{mol} \cdot \mathrm{m}^{-2} \cdot \mathrm{s}^{-1} P A R$. For each experiment a minimum of four replications were used for longevity and respiration measurements.

All experiments consisted of completely randomized designs. To assess differences among cultivar longevity or flower respiration, analysis of variance (ANOVA) was performed and treatment means compared using Duncan's multiple range test (General Linear Models Procedure, SAS software, SAS Inst., Inc., Cary, N.C.). For each experiment and day of respiration measurement, linear correlations were run between the cultivar means of flower longevity and flower respiration (Regression Procedure, SAS software). Experiments were pooled into two seasons, spring/summer (Expts. 1 and 2) and fall/winter (Expts. 3 and 4) and, for each season, linear correlations were run between flower longevity and flower respiration (Regression Procedure, SAS software).

For day 2 under interior conditions, all the experiments were pooled, the variable season introduced, and ANOVA performed (General Linear Models Procedure, SAS software) as a factorial experiment ( 2 seasons $\times 5$ cultivars). Day 2 was chosen because

Fig. 1. (A) Flower longevity and (B) flower respiration for day 2 under interior conditions. Five experiments were pooled and treated as a $2 \times 5$ factorial $(2$ seasons $\times 5$ cultivars). Each symbol is the mean of the two experiments $(n \geq 8)$ for that specific season. All main effects were significant at $P=0.0001$. For (A) flower longevity, there was an interaction between season and cultivar: 'Meijikatar' and 'Meirutral' had shorter longevities in fall/winter than in spring/ summer (at $P=0.0001$ ), while the other cultivars had similar longevities in both seasons. Cultivar means comparison by Duncan's multiple range test at $P=0.05$ for a fixed season is shown in the graph: means followed by the same letter are not significantly different. For (B) flower respiration, there was no interaction between season and cultivar: it was higher in spring/summer than in fall/winter and it was lower in 'Meijikatar' and 'Meirutral ' than in the other cultivars (Duncan's multiple range test at $P=0.05$ ).
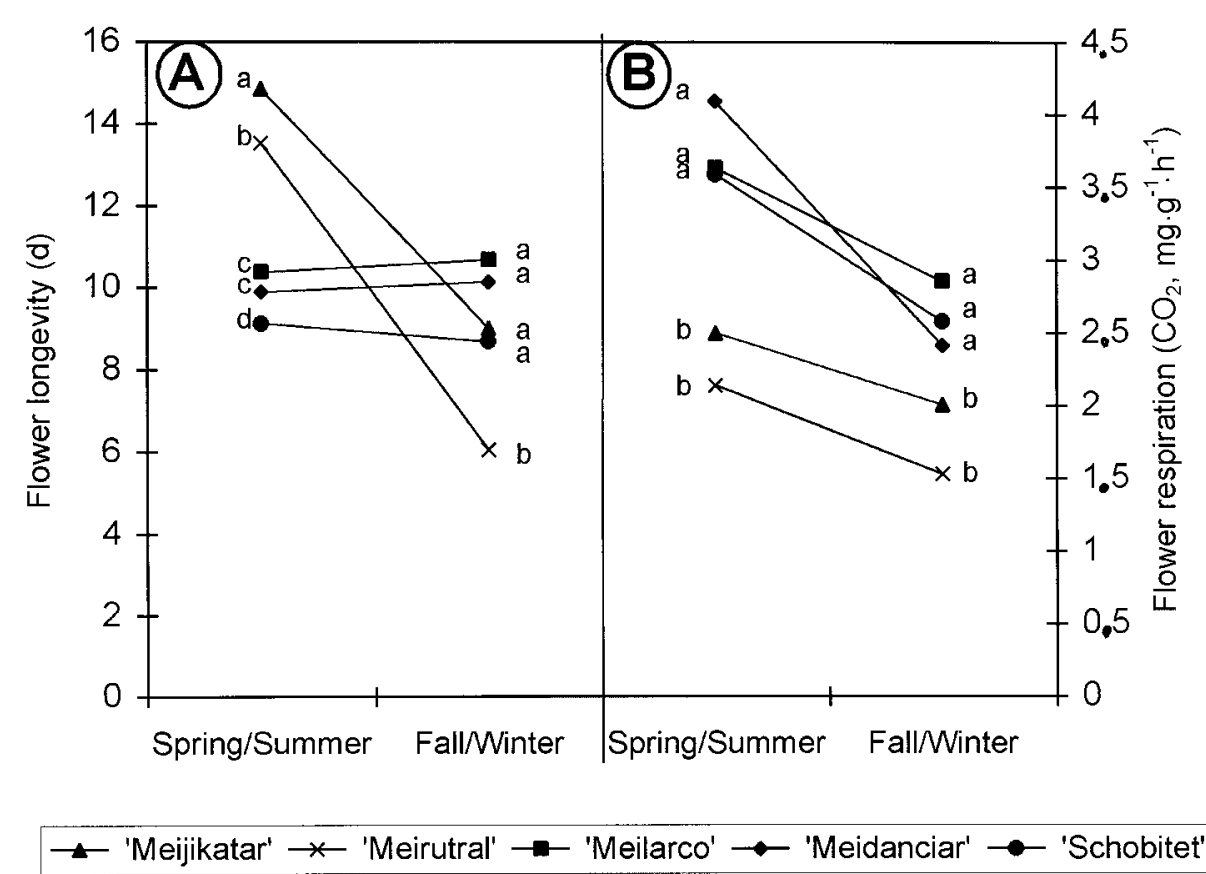
Table 1. Level of significance ( $P$ value) and slopes for the regressions between the cultivar means of flower longevity and flower respiration, for each experiment, and for plants under both interior and greenhouse conditions

\begin{tabular}{|c|c|c|c|c|c|c|c|c|c|c|c|}
\hline \multirow[b]{2}{*}{ Experiment } & \multirow[b]{2}{*}{ Day E } & \multicolumn{5}{|c|}{ Interior conditions ${ }^{\mathrm{z}}$} & \multicolumn{5}{|c|}{ Greenhouse conditions } \\
\hline & & Day $0^{y}$ & Day 2 & Day 4 & Day 6 & Day 8 & Day $0^{y}$ & Day 2 & Day 4 & Day 6 & Day 8 \\
\hline 1. (April 1992) & & & & & & & & & & & \\
\hline $\begin{array}{l}\text { Significant at } P= \\
\text { Slope }\end{array}$ & NS & NS & NS & NS & NS & NS & NS & NS & NS & NS & $\begin{array}{c}0.01 \\
-5.86\end{array}$ \\
\hline $\begin{array}{l}\text { 2. (June 1991) } \\
\text { Significant at } P= \\
\text { Slope }\end{array}$ & NS & $\begin{array}{c}0.02 \\
-3.60\end{array}$ & $\begin{array}{c}0.09 \\
-3.16\end{array}$ & $\mathrm{NR}^{\mathrm{x}}$ & NR & NR & NS & NS & NR & NR & NR \\
\hline $\begin{array}{l}\text { 3. }(\text { November } 1991) \\
\text { Significant at } P= \\
\text { Slope }\end{array}$ & NS & NS & NS & NS & $\mathrm{IF}^{\mathrm{w}}$ & NS & $\begin{array}{l}0.09 \\
1.68\end{array}$ & $\begin{array}{l}0.06 \\
3.56\end{array}$ & NS & IF & $\begin{array}{l}0.06 \\
3.99\end{array}$ \\
\hline $\begin{array}{l}\text { 4. (February } 1992) \\
\text { Significant at } P= \\
\text { Slope }\end{array}$ & NS & NS & $\begin{array}{l}0.06 \\
3.06\end{array}$ & NS & NS & NS & $\begin{array}{l}0.01 \\
7.02\end{array}$ & NS & NS & NS & NS \\
\hline
\end{tabular}

Interior rooms provided $21 \pm 1^{\circ} \mathrm{C}$ and $50 \pm 5 \%$ relative humidity with a $12 \mathrm{~h}$ photoperiod of $12 \mu \mathrm{mol} \cdot \mathrm{m}^{-2} \cdot \mathrm{s}^{-1}$ irradiance $(P A R)$

${ }^{\mathrm{y}}$ Day $0=$ flower anthesis.

${ }^{\mathrm{x}} \mathrm{NR}=$ Data not recorded .

wData not recorded due to insuficient number of flowers.

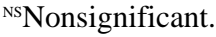

flower respiration rate is free from the quick changes caused by anthesis and from the variability induced by senescence. Under interior conditions the environmental factors are easily repeatable.

\section{Results and Discussion}

The pattern of flower senescence varied with cultivar. 'Meirutral' and 'Meijikatar' miniature roses dropped flowers while 'Meidanclar' and 'Meilarco' exhibited petal browning followed by petal drop. 'Schobitet' petals became discolored simultaneously with petal drop.

There was an interaction between cultivar and season with regards to flower longevity (Fig. 1A). 'Meijikatar' and 'Meirutral', the cultivars with the lowest respiration rates, had higher longevities if grown in spring/summer (15 and $14 \mathrm{~d}$, respectively) than if grown in fall/winter (9 and $6 \mathrm{~d}$ respectively), agreeing with reports of Chen (1990) and Kyalo et al. (1996). The other three cultivars,

Fig. 2. Spring/summer experiments (Expts. 1 and 2). Correlation of flower longevity under interior conditions with flower respiration at different times and environments: (A) at anthesis under interior conditions: $\mathrm{Y}=25.039-3.908 \mathrm{x}$, significant at $P=$ 0.0014 ; (B) $2 \mathrm{~d}$ after anthesis under interior conditions: $\mathrm{Y}=21.39-3.039 \mathrm{x}$, significant at $P=$ $0.0051 ;(\mathbf{C})$ at anthesis in the greenhouse: $\mathrm{Y}=19.32$ - 1.89x, significant at $P=0.055$; (D) $2 \mathrm{~d}$ after anthesis in the greenhouse: $\mathrm{Y}=16.52-1.348 \mathrm{x}$, significant at $P=0.0778$. Interior rooms provided $21 \pm 1{ }^{\circ} \mathrm{C}$ and $50 \pm 5 \%$ relative humidity with a 12 $\mathrm{h}$ photoperiod of $12 \mu \mathrm{mol} \cdot \mathrm{m}^{-2} \cdot \mathrm{s}^{-1}(P A R)$. Each symbol represents the mean $(n \geq 4)$ of a cultivar for a specific experiment. Solid symbols (as in the legend) are from the June experiment, and open symbols are from the April experiment.
'Meidanclar', 'Meilarco', and 'Schobitet' did not show differences in longevity between spring/summer (lasting 10, 11, and 9 $\mathrm{d}$, respectively) and fall/winter (lasting 10, 10, and $9 \mathrm{~d}$, respec-

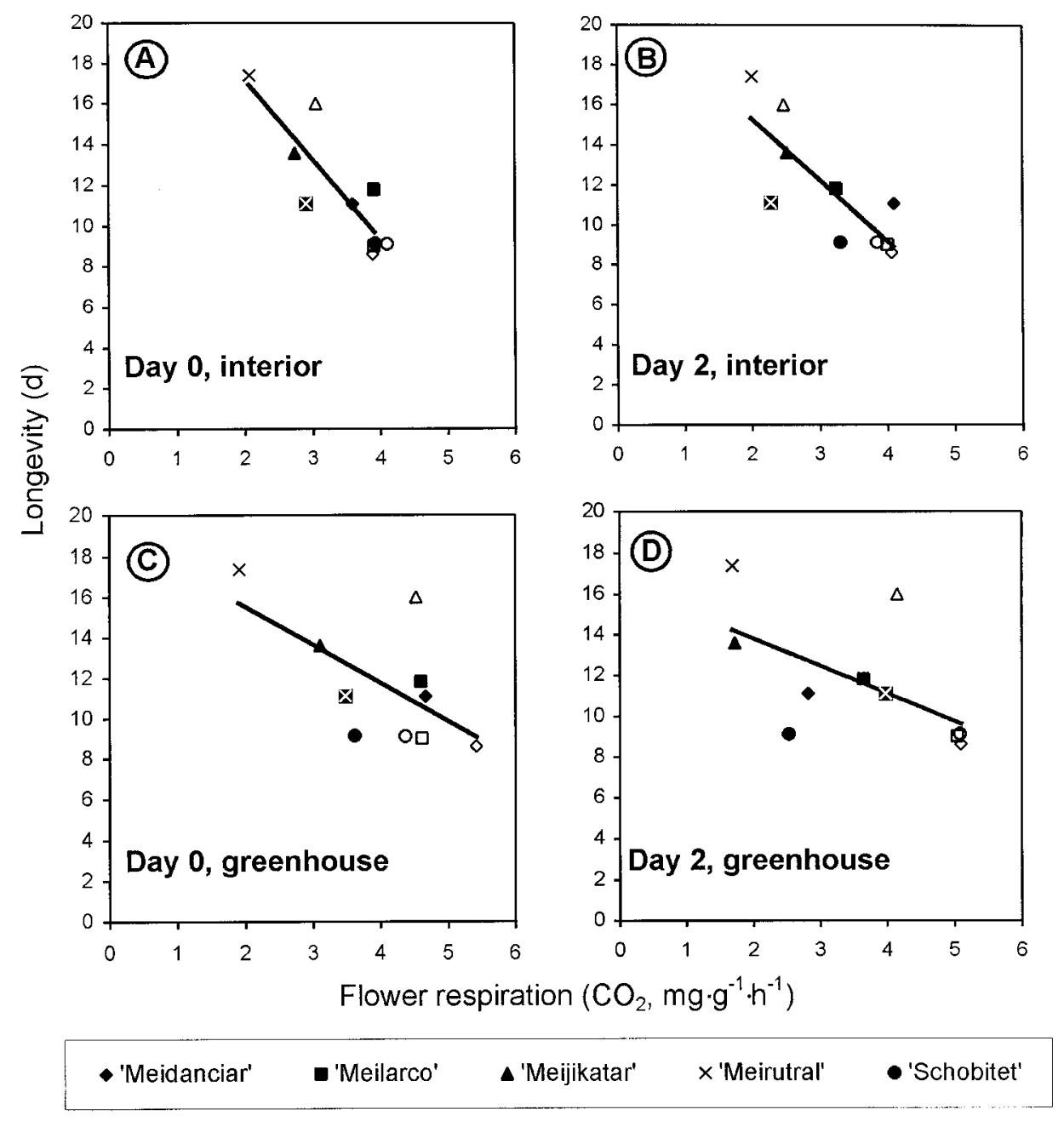




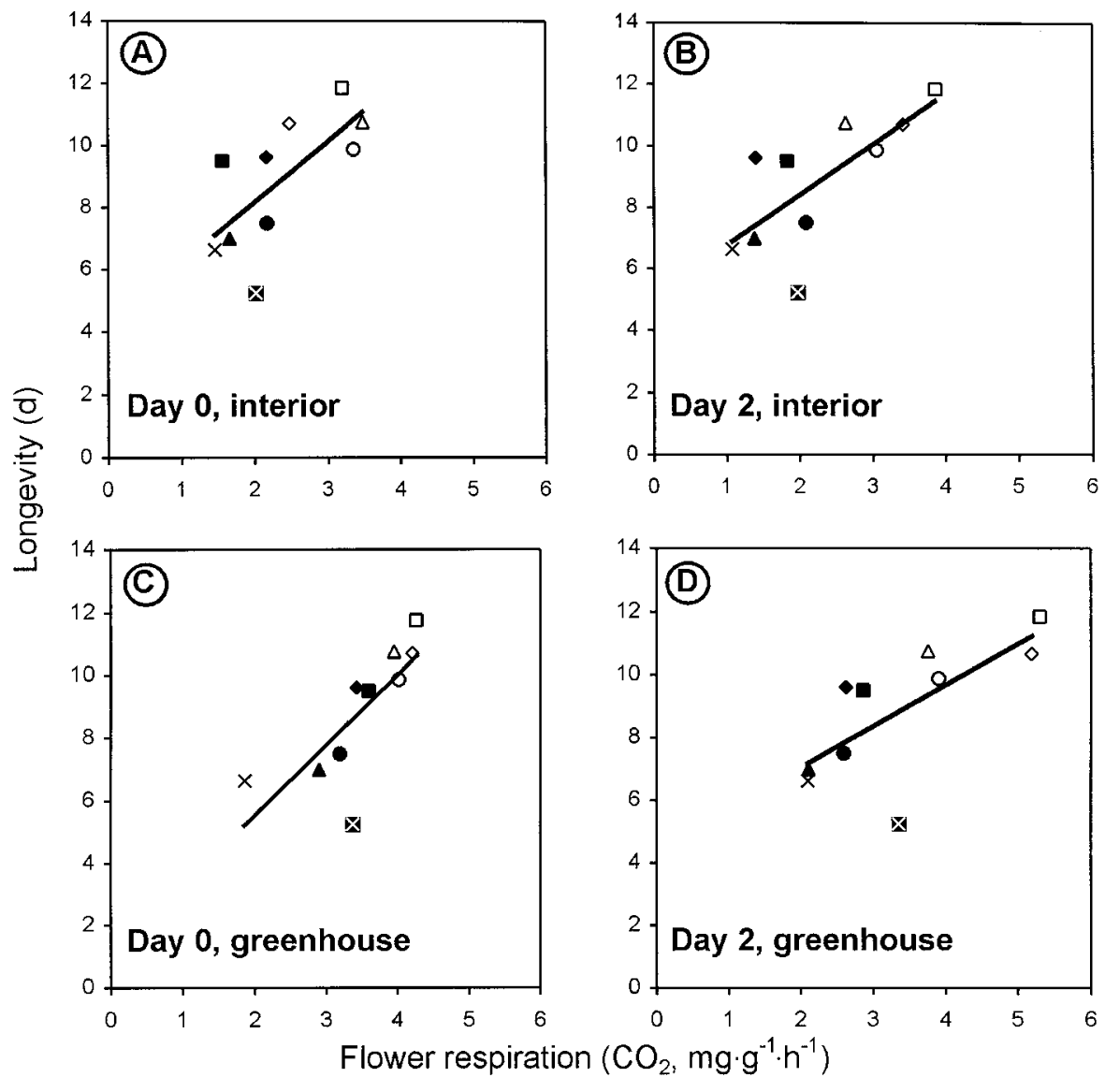

- 'Meidanciar' $\quad$ 'Meilarco' $\quad$ 'Meijikatar' $\quad \times$ 'Meirutral' $\quad$ 'Schobitet'
The only type of correlations found were negative.

For day 0 and day 2, pooling the data from all spring/summer experiments [Expts. 1 (April) and 2 (June)] revealed negative correlations between flower longevity and flower respiration (Fig. 2) for plants under interior conditions and in the greenhouse.

Genotype appeared to be the main factor determining the relationship between flower longevity and flower respiration since data are scattered along the regression lines for plants under interior conditions or plants in the greenhouse at anthesis. At day 2 for plants in the greenhouse, data for each experiment are grouped (Fig. 2D) at different sides of the regression line, suggesting that environmental factors (i.e., the different conditions of each experiment) were becoming of greater importance as a source of variability. The dominance of environment (at day 2 in the greenhouse) over the genotype induced variability is understandable since these plants remained in the greenhouse for two more days than plants at day 0 in the greenhouse. Conditions in the greenhouse may vary widely in a short period of time and, probably, respiration of older flowers is more sensitive to environmental conditions than respiration of flowers at anthesis.

The negative correlations between flower longevity and flower respiration, found previously for cut flowers (Kuc and Workman, 1964) and potted chrysanthe-

Fig. 3. Fall and winter experiments (Expts. 4 and 5). Correlation of flower longevity under interior conditions with flower respiration at different times and environments: (A) at anthesis under interior conditions: $\mathrm{Y}=4.26+1.96 \mathrm{x}$, significant at $P=0.027 ;(\mathbf{B}) 2 \mathrm{~d}$ after anthesis under interior conditions: $\mathrm{Y}=5.11$ $+1.65 \mathrm{x}$, significant at $P=0.018 ;(\mathbf{C})$ at anthesis in the greenhouse: $\mathrm{Y}=1.04+$ $2.25 \mathrm{x}$, significant at $P=0.010$; and (D) $2 \mathrm{~d}$ after anthesis in the greenhouse: $\mathrm{Y}$ $=4.44+1.31 \mathrm{x}$, significant at $P=0.022$. Interior rooms provided $21 \pm 1{ }^{\circ} \mathrm{C}$ and $50 \pm 5 \%$ relative humidity with a 12 -h photoperiod of $12 \mu \mathrm{mol} \cdot \mathrm{m}^{-2} \cdot \mathrm{s}^{-1}(P A R)$. Each symbol represents the mean $(n \geq 4)$ of a cultivar for a specific experiment. Solid symbols (as in the legend) are from the November experiment, open symbols are from the February experiment.

tively). For spring/summer, 'Meijikatar' lasted the longest, followed by 'Meirutral', which was followed jointly by 'Meidanclar' and 'Meilarco', and 'Schobitet' had the shortest longevity of all cultivars. For fall/winter these cultivars had similar longevities with the exception of 'Meirutral', which had a shorter longevity.

For day 2 under interior conditions, there was no interaction between season and cultivar for respiration. Flower respiration (Fig. 1B) was higher if the plants were produced during spring/ summer (the mean of the five cultivars in $\mathrm{CO}_{2}$ per gram DW was $3.17 \mathrm{mg} \cdot \mathrm{g}^{-1} \cdot \mathrm{h}^{-1}$ ) than if produced during fall/winter (the mean of the five cultivars was $\left.2.12 \mathrm{mg} \cdot \mathrm{g}^{-1} \cdot \mathrm{h}^{-1}\right)$. 'Meidanclar', 'Schobitet' and 'Meilarco' always had higher respiration rates (the mean of the two seasons was $2.99,2.98$, and $2.91 \mathrm{mg} \cdot \mathrm{g}^{-1} \cdot \mathrm{h}^{-1}$, respectively) than 'Meijikatar' or 'Meirutral' (the mean of the two seasons was 2.16 and $1.75 \mathrm{mg} \cdot \mathrm{g}^{-1} \cdot \mathrm{h}^{-1}$, respectively).

SPRING/SUMMER EXPERIMENTS. For spring/summer experiments, most dates of respiration assessment showed no correlations between flower longevity and flower respiration (Table 1). mum (Monteiro, 1991), are thus confirmed for potted miniature roses grown during spring/summer.

The hypothesis of Pearl (1928) that the higher the rate of energy expenditure during life, the shorter the life span is also confirmed. Pearl (1928) worked with cantaloupe seedlings with a limited energy supply (i.e., the seed reserves) and suggested that the rate of using that energy (he called it inherent vitality) is intrinsic to the seed (i.e., genetically determined). The metabolic experiments of Pearl (1928) also suggested that seedlings with high metabolic rates use more dry matter but it is not clear if they were less efficient than the ones with low metabolic rates. Longer longevities could result from performing the same tasks at a slower rate and/or from a more efficient use of the energy available.

Miniature roses under interior conditions (where longevity was always determined) are under a limited energy supply. In the present research, it was assumed that leaving only one flower per plant would ensure that overall reserves in the plant were sufficient for the flower to complete its development since plants in these conditions are able to support several flowers (Høyer et al., 1996; Kyalo et al., 1996). With this assumption-at least for spring/summer-low respiration rates, as related to an increased efficiency in using a limited energy supply, loses importance. The most acceptable explanation is that the plant organ is genetically programmed to develop slowly. Nevertheless, the environment interacts with the genetic program modifying it, as it probably happened in day 2 in the greenhouse. Environmental conditions must be adequate for the fully expression of a character (Pearl, 
1928) otherwise they may allow for the expression of other characters modifying the overall response, as it most probably happened in the fall/winter experiments.

FALL/WINTER EXPERIMENTS. For the separate fall/winter experiments and the different dates flower respiration was assessed, correlations between flower longevity and flower respiration were also difficult to show. The only ones that appeared were positive ones (Table 1).

For day 0 and day 2, pooling the data from all fall/winter experiments [Expts. 3 (November) and 4 (February)] showed positive correlations between flower longevity and flower respiration (Fig. 3) for both greenhouse and interior conditions. Variability was induced mostly by experiment, with data for each experiment being grouped on different regions of the regression line. Probably, an environmentally induced constraint in flower respiration overcame the cultivar induced variation, i.e., the cultivar metabolic rate.

In plants, increased respiration rates may signify, simultaneously or separately, several things: 1) a burst in synthetic activity, as at flower opening (Nakamura et al., 1975) or intense growth periods (Geider and Osborne, 1989; Kallarackal and Milburn, 1985); 2) a high intrinsic metabolic rate or a high energetic need for maintenance (Wilson, 1975); 3) an increased need to repair, as after a stressful stimulus (Reid and Pratt, 1972; Romani et al., 1968); 4) an ultimate effort to maintain homeostasis as in the climacteric commodities (Romani, 1987); or 5) release of a substrate limitation, as in cut flowers in a vase solution with sucrose (Marousky, 1969; Nichols, 1973; van der Merwe et al., 1986).

Similarly to cut flowers without an exogenous sugar supply, respiration rate during fall/winter, appears to be a limiting factor for flower longevity. This work supports the hypothesis that whenever flower development is under respiratory restraints, releasing the restraints, increases respiration and flower longevity simultaneously. This may explain why exogenous sugar supply on cut flowers and environmental conditions on potted plants may increase flower longevity and flower respiration simultaneously (Çelikel and Karaçali, 1991; Marousky, 1969; Nichols, 1973; van der Merwe et al., 1986). Comparing to spring/ summer, fall/winter conditions decreased flower respiration in all cultivars tested but longevity did not decrease in all of them. 'Meijikatar' and 'Meirutral', the cultivars that had their longevity affected by the season, were the ones with the lower respiration rates (Fig. 1) and thus are the ones where it is easier for respiration to be a limiting factor. The cultivars that did not reduce their longevities in fall/winter were the ones with higher respiration rates and, even with the seasonal reduction, flower respiration for these cultivars was never as low as in 'Meijikatar' or 'Meirutral'. Possibly, the reduction in flower respiration experienced in fall/winter by 'Meilarco', 'Meidanclar', and 'Schobitet' was not enough to have detrimental starvation effects on flower longevity.

Gent and Enoch (1983) using a mathematical model for tomato (Lycopersicon esculentum Mill.) and carnation growth, concluded that plant growth at low temperatures is limited by a shortage of respiratory energy. Similar respiratory restrictions may be related to differences observed in these studies.

Temperate zone plants, grown at low temperatures (or during winter) increase their carbohydrate levels or at least increase their partitioning priorities to storage carbohydrates, as starch. Tall fescue [Festuca elatior L. (syn. F. arundinacea Schreb.)] total carbohydrate content is much higher in winter than in other seasons (Razmjoo et al., 1997). Starch levels in chrysanthemum stems are much higher in fall than in spring (Rajapakse and Kelly, 1995). In roses, plants grown at low night temperatures $\left(12^{\circ} \mathrm{C}\right)$ have higher leaf starch levels than plants grown at warm $\left(18^{\circ} \mathrm{C}\right)$ nights (Khayat and Zieslin, 1986). Some preliminary work (Monteiro, unpublished) with 'Meirutral' and 'Meidanclar' miniature roses also shows higher plant carbohydrate levels if plants are grown under lower temperatures (days/nights of $24 / 18{ }^{\circ} \mathrm{C}$ ) compared to higher growing temperatures (days/nights of 29/24 ${ }^{\circ} \mathrm{C}$ ). Therefore, it seems that in potted miniature roses, reduced flower respiration (and longevity) is not the result of lack of carbohydrate reserves but rather a lack of carbohydrate availability, due to modified assimilate partitioning. This hypothesis is supported by the work of Khayat and Zieslin (1986) with roses, where low night temperatures reduced the export of assimilates from source leaves into adjacent axillary buds and promoted their transport towards basal plant parts. Also, low night temperatures reduce import of assimilates to the flower petals, as well as the levels of reducing sugars in flower petals (Khayat and Zieslin, 1989).

Assimilate partitioning was shown previously to be under environmental control. Reduced irradiance was reported to decrease assimilate partitioning to rose shoots, impairing flower development (Mor and Halevy, 1980). Photoperiod can also modify assimilate partitioning in cucumber (Cucumis sativus L.) (Robbins and Pharr, 1987) and rabbiteye blueberry (Vaccinium ashei Reade) (Darnell, 1991).

The current studies show that correlations between flower longevity under interior conditions and flower respiration are similar for plants maintained in the greenhouse or interior conditions, confirming the effect of a past environment on plant development.

Flower respiration can be an important indicator of flower longevity. However, the interaction between environment and genotype limits its application under commercial conditions as an absolute postproduction longevity indicator. The existence of an universal optimum for flower respiration is not probable either: 'Meijikatar' miniature rose flower respiration in spring/summer is similar to 'Meidanclar' flower respiration in fall/winter but their longevities differ by about $4 \mathrm{~d}$. Nevertheless, data provide evidence that the best cultivars to grow during fall/winter are the ones with higher respiration rates while for spring/summer production, cultivars with low respiration rates should be used. Increasing fall/winter growing temperature, as suggested by Kyalo et al. (1996), may not be useful for some miniature rose cultivars like 'Meidanclar', 'Meilarco' or 'Schobitet'.

\section{Literature Cited}

Adelman, R., R.L. Saul, and B.N. Ames. 1988. Oxidative damage to DNA: Relation to species metabolic rate and life span. Proc. Natl. Acad. Sci. USA 85:2706-2708.

Borch, K., M.H. Williams, and L. Høyer. 1996. Influence of simulated transport on postharvest longevity of three cultivars of miniature potted rose. Acta Hort. 424:175-180.

Çelikel, F.G. and I. Karaçali. 1991. A study of longevity of cut carnation (Dianthus caryophyllus L.) grown in Yalova (Istanbul). Acta Hort. 298:111-118.

Chen, L.L. 1990. Growth regulator reversal of simulated high temperature shipping effects on flower senescence and leaf abscission in miniature potted rose plants. MS thesis, Texas A\&M Univ., College Station.

Clark, D.G., J.W. Kelly, and N.C. Rajapakse. 1993. Production and postharvest characteristics of Rosa hybrida L. 'Meijikatar' grown in 
pots under carbon dioxide enrichment. J. Amer. Soc. Hort. Sci. 118:613617.

Cushman, L.C., H.B. Pemberton, and J.W. Kelly. 1994. Cultivar, flower stage, silver thiosulfate, and BA interactions affect performance of potted miniature roses. HortScience 29:805-808.

Cushman, L.C., H.B. Pemberton, J.C. Miller, Jr., and J.W. Kelly. 1998. Interactions of flower stage, cultivar, and shipping temperature and duration affect pot rose performance. HortScience 33:736-740.

Darnell, R.L. 1991. Photoperiod, carbon partitioning, and reproductive development in rabbiteye blueberry. J. Amer. Soc. Hort. Sci. 116:856860.

Geider, R.J. and B.A. Osborne. 1989. Respiration and microalgal growth: A review of the quantitative relationship between dark respiration and growth. New Phytol. 112:327-341.

Gent, M.P.N. and H.Z. Enoch. 1983. Temperature dependence of vegetative growth and dark respiration: A mathematical model. Plant Physiol. 71:562-567.

Høyer, L., K. Borch, and M.H. Williams. 1996. Post production quality of pot roses: A result of interaction between cultivar, post-production conditions and numbers of open flowers at the time of sale. Acta Hort. 424:191-193.

Jiao, J., X. Wang, and M.J. Tsujita. 1990. Whole plant net photosynthesis of miniature roses influenced by light, $\mathrm{CO}_{2}$ and temperature. Acta Hort. 272:261-265.

Kader, A.A. 1985. Postharvest biology and technology: An overview, p.3. In: A.A. Kader, R.F. Kasmire, F.G.Mitchell, M.S. Reid, N.F. Sommer, and J.F. Thompson (eds.). Postharvest technology of horticultural crops. Univ. Calif. Coop. Ext. Serv., Div. of Agr. and Natural Resources. Spec. Publ. 3311.

Kallarackal, J. and J.A. Milburn. 1985. Respiration and phloem translocation in the roots of chickpea (Cicer arietinum). Ann. Bot. 56:211218.

Khayat, E. and N. Zieslin. 1986. Effect of different night temperature regimes on the assimilation transport and metabolism of carbon in rose plants. Physiol. Plant. 67:608-613.

Khayat, E. and N. Zieslin. 1989. Translocation of ${ }^{14} \mathrm{C}$, carbohydrate content and activity of the enzymes of sucrose metabolism in rose petals at different night temperatures. Physiol. Plant. 76:581-585.

Kuc, R. and M. Workman. 1964. The relation of maturity to the respiration and keeping quality of cut carnations and chrysanthemums. Proc. Amer. Soc. Hort. Sci. 84:575-581.

Kyalo, T.M., H.B. Pemberton, and J. M. Zajicek. 1996. Seasonal growing environment affects quality characteristics and postproduction longevity of potted miniature roses. HortScience 31:120-122.

Marousky, F.J. 1969. Vascular blockage, water absorption, stomatal opening, and respiration of cut 'Better times' roses treated with 8-hydroxyquinoline citrate and sucrose. J. Amer. Soc. Hort. Sci. 94:223-226.

Monteiro, J.A. 1991. Potted chrysanthemum postproduction longevity: Carbon exchange rates, dry matter and nonstructural carbohydrates. MS thesis, Univ. Fla., Gainesville.

Mor, Y. and A.H. Halevy. 1980. Promotion of sink activity of developing rose shoots by light. Plant Physiol. 66:990-995.

Nakamura, R., T. Ito, and K. Hirano. 1975. Changes of the respiration rates in cut flowers. Scientific Rpt. Faculty of Agr., Okayama Univ., Okayama, Japan 46:29-37.

Nichols, R. 1973. Senescence of the cut carnation flower: Respiration and sugar status. J. Hort. Sci. 48:111-121.

Pearl, R. 1928. Experiments on longevity. Quarterly Rev. Biol. 3:391407.

Rajapakse, N.C., D.G. Clark, J.W. Kelly, and W.B. Miller. 1994. Carbohydrate status and postharvest leaf chlorosis of miniature roses as influenced by carbon dioxide enrichment. Postharvest Biol. Technol. 4:271-279.

Rajapakse, N.C. and J.W. Kelly. 1995. Spectral filters and growing season influence growth and carbohydrate status of chrysanthemum. J. Amer. Soc. Hort. Sci. 120:78-83.

Razmjoo, K., T.Imada, J. Sugiura, and S. Kaneko. 1997. Seasonal variations in nutrient and carbohydrate levels of tall fescue cultivars in Japan. J. Plant Nutr. 20:1667-1679

Reid, M.S. 1985. Postharvest handling systems: Ornamentals, p. 174. In: A.A. Kader, R.F. Kasmire, F.G. Mitchell, M.S. Reid, N.F. Sommer, and J.F. Thompson (eds.). Postharvest technology of horticultural crops. Univ. Calif. Coop. Ext. Serv., Div. of Agr. and Natural Resources. Spec. Publ. 3311

Reid, M.S. and H.K. Pratt. 1972. Effects of ethylene on potato tuber respiration. Plant Physiol. 49:252-255.

Robbins, N.S. and D.M. Pharr. 1987. Regulation of photosynthetic carbon metabolism in cucumber by light intensity and photosynthetic period. Plant Physiol. 85:592-597.

Romani, R.J. 1987. Senescence and homeostasis in postharvest research. HortScience 22:865-868.

Romani, R.J., I.K. Yu, L.L. Ku, L.K. Fisher, and N. Dehgan. 1968. Cellular senescence, radiation damage to mitochondria, and the compensatory response in ripening pear fruits. Plant Physiol. 43:1089-1096.

van der Merwe, J.J., G.H. de Swardt, and L. Burger. 1986. The effects of sucrose uptake from a vase medium on the starch metabolism of senescing Gladiolus inflorescences. S. Afr. J. Bot. 52:541-545.

Wilson, D. 1975. Variations in leaf respiration in relation to growth and photosynthesis of Lolium. Ann. Appl. Biol. 80:323-338. 